\title{
12. SIGNIFICANCE OF PLANT REMAINS IN REDEPOSITED APTIAN SEDIMENTS, HOLE 462A, NAURU BASIN, TO CRETACEOUS OCEANIC-OXYGENATION MODELS ${ }^{1}$
}

\author{
Hugh C. Jenkyns, Department of Geology and Mineralogy, University of Oxford, England \\ and \\ Seymour O. Schlanger, Hawaii Institute of Geophysics, Honolulu, Hawaii
}

\begin{abstract}
Carbonized plant remains occur in an 80-cm-thick section of upper Aptian gray claystones that apparently constitute a raft within the Cretaceous basaltic igneous complex of Hole $462 \mathrm{~A}$. The sediments are streaked out, suggesting local redeposition, and the plant remains are concentrated in select laminae. Organic carbon values of the total sediment are around $0.2 \%$. Given that the sediments were caught up in the igneous complex, and that their age is compatible with deposition before major extrusive and intrusive activity, their depositional depth must have been about $5 \mathrm{~km}$. These plant remains comprise the type of degraded organic matter that could readily survive and accumulate in oxygenated water, and hence the Cretaceous oxygen-minimum model for the Pacific remains viable: there is no compelling evidence for anoxic bottom waters. Although local control, in the form of neighboring vegetated islands, can apparently impose a predominantly terrestrial signature on the organic carbon deposited in adjacent basinal areas throughout the Cretaceous, there is some evidence for a regional change in the type of material deposited from predominantly landderived higher plant in the Aptian to planktonic in the Albian-Cenomanian. Such a change in the Pacific record, if real, has parallels in the Atlantic Ocean, and may perhaps be a global phenomenon: if so, it defines an important difference between the nature of the Early and Late Cretaceous oceanic anoxic events.
\end{abstract}

\section{INTRODUCTION}

In recent years, considerable interest has centered on the occurrence and significance of those pelagic Cretaceous sediments that are rich in organic carbon (e.g., Schlanger and Jenkyns, 1976; Fischer and Arthur, 1977; Ryan and Cita, 1977; Thiede and van Andel, 1977; Arthur and Natland, 1979; Jenkyns, 1980). Certain of these authors have suggested that an enhanced or expanded oxygen-minimum layer characterized the Pacific Ocean at certain intervals (Barremian-Aptian-Albian and Cenomanian-Turonian) during the Cretaceous: these intervals define the duration of so-called Oceanic Anoxic Events. Implicit in the oxygen-minimum model, of course, is the idea that bottom waters contained higher oxygen contents than those in the column directly above. There remains, however, the possibility that these abyssal waters were also anoxic or at least poorly ventilated. Thus, Hole $462 \mathrm{~A}$, with its considerable predicted Cretaceous depositional depths, seemed to offer promise as a possible test for the oxygen-minimum model. Clearly, however, the intrusion of the Nauru Basin igneous complex (site chapter, this volume) has violated the simple age-depth relationship of ocean floor (Schlanger and Premoli Silva, this volume), and assessment of Cretaceous depths is at best based on a series of approximations.

\section{DESCRIPTION OF UPPER APTIAN DEPOSITS}

Deposits, probably upper Aptian, were recovered sandwiched between basalt in Section 462A-40-1; the thickness of the section is some $80 \mathrm{~cm}$. The sediments

\footnotetext{
1 Initial Reports of the Deep Sea Drilling Project, Volume 61.
}

are dark gray laminated claystones, locally zeolitic. The laminations appear to be the result of streaking out by soft-sediment slippage, rather than a primary depositional feature (cf. the phacoidal structures of Voigt, 1962), an interpretation given weight by the fact that the laminae depart from the horizontal by up to $10^{\circ}$. Some coarser layers of volcaniclastic siltstone are intercalated in this otherwise clay-dominated sequence.

The notable feature of this deposit is the presence of tiny (millimeter-scale or less) fragments of carbonized plant and/or wood fragments, some of which are covered by a patina of pyrite (Figs. 1 and 2). These black flecks are selectively concentrated along certain laminae. Shipboard analyses of the organic carbon content of the total sediment gave $0.13 \%$ for Sample $462 \mathrm{~A}-40-1,110-112 \mathrm{~cm}$ and $0.25 \%$ for Sample $462 \mathrm{~A}-$ $40-1,128-130 \mathrm{~cm}$. A repeat analysis of the latter sample, undertaken at Oxford University, gave $0.19 \%$ organic carbon.

This horizon, on the basis of a poorly preserved nannofossil assemblage, is probably upper Aptian (Thierstein, this volume). This flora consists of over $99 \%$ Watznaueria barnesae, which may represent a dissolution facies: all other sediments from within the igneous complex were barren of nannoliths. Deep-water agglutinated foraminifers are present. These are represented by poorly preserved, rare specimens of largely primitive species associated with radiolarians, fish debris, sponge spicules, and the plant debris (Premoli Silva, this volume).

\section{DEPTH OF DEPOSITION}

Although the significance of this find must not be overstressed, the organic-carbon level in this horizon is 


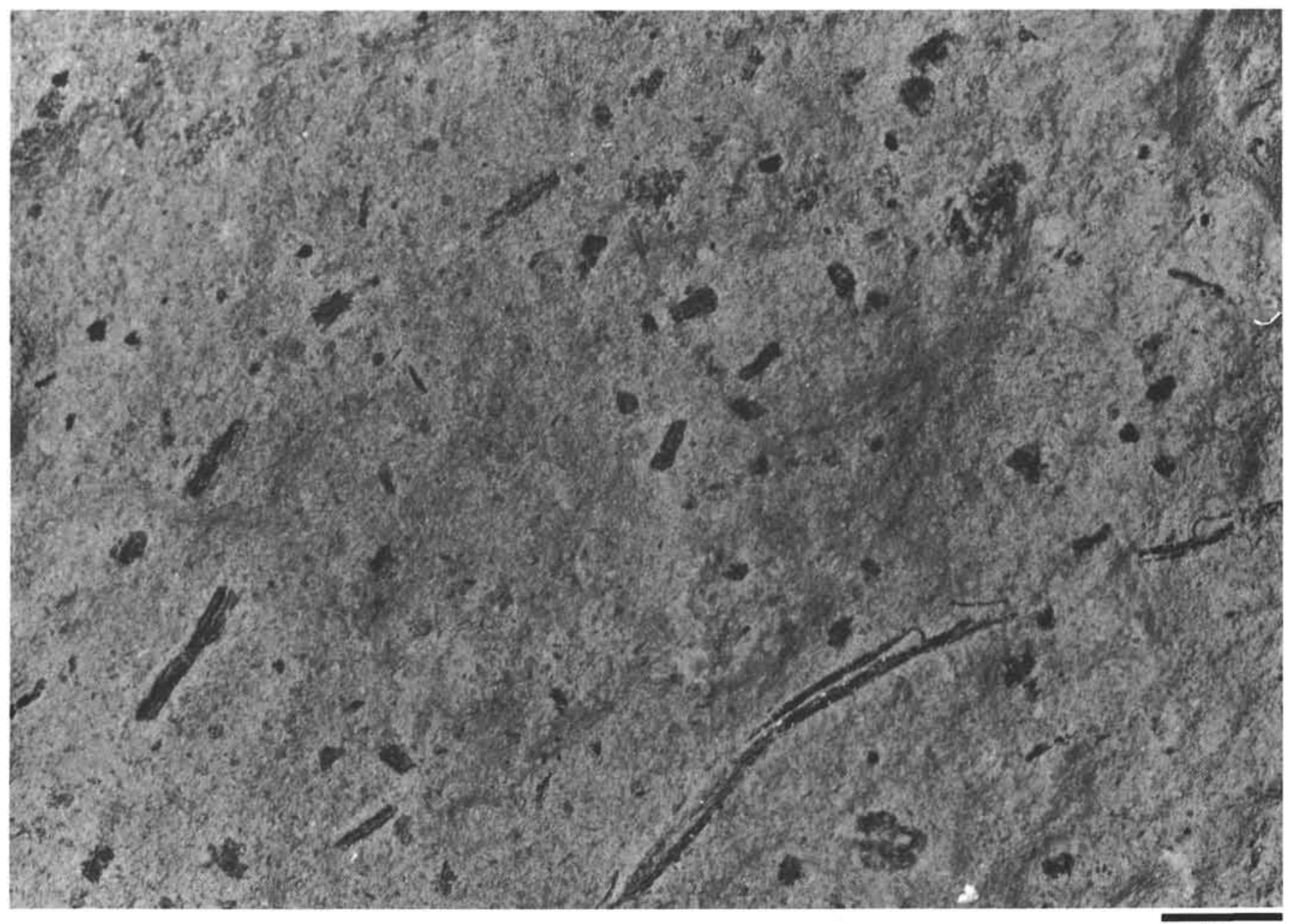

$1 \mathrm{~mm}$

Figure 1. Upper Aptian dark gray claystone containing abundant carbonized plant remains.

higher than for recent abyssal red clays; and the presence of such quantities of plant material is unusual in pelagic sediments. Furthermore, given that organic carbon contents in Recent sediments decrease with distance below the sediment/water interface, the organic carbon levels in this Aptian deposit would have been higher when it was first laid down (cf. Heath et al., 1977), which precludes any direct comparison with the values in Recent sediments. Moreover, given that this sediment is a raft within the igneous complex, it is possible that greater quantities of organic matter were originally present, the carbonized plant debris being all that has run the thermal gauntlet. Thus arises the question of whether these remains signify poorly oxygenated conditions at this site. Elsewhere in the Pacific, reported carbonaceous sediments of similar age have been sampled only from rises, plateaus, or submarine mountain ranges that may have projected upward into an oxygenminimum zone: Shatsky Rise, Site 305, Barremian-Aptian; Manihiki Plateau, Site 317, Barremian-Aptian; the western mid-Pacific mountains, Site 463, lower Aptian; Hess Rise, Site 465, Albian-Cenomanian (Larson, Moberly, et al., 1975; Schlanger, Jackson, et al., 1976; Vallier and Thiede, 1979). The carbonaceous limestone of Site 463, associated with lower Aptian volcanic ash, contains up to $4 \%$ organic carbon, a significant proportion of which is land-derived material, according to Dean et al. (1979). These authors consider the terrestrial nature of the organic material as indicative of the former presence of numerous volcanic islands. At Site 465 on the southern Hess Rise, dark-colored upper Albian to lower Cenomanian limestones contain organic carbon derived largely from aquatic marine organisms (Dean et al., 1979). Using evidence from these sites and elsewhere, we may thus postulate the former presence of an expanded girdle of oxygen-depleted intermediate waters around the mid-Cretaceous globe (Figure 3).

What remains problematical, however, is the depositional depth of the plant remains at Site 462 . If we assume that the deposit was laid down in the late Aptian and cross-reference this against a curve showing the subsidence-uplift history of Site 462 shown in Figure 4, we arrive at a depositional depth for the Nauru Basin of $\sim 5 \mathrm{~km}$, considerably greater than that estimated for those Pacific plateaus that carry organic carbon-rich sediments $(\sim 2 \mathrm{~km}$, after Thierstein, 1979). Since the plant-bearing sediments are within the igneous complex, we can assume that they were deposited before the onset 


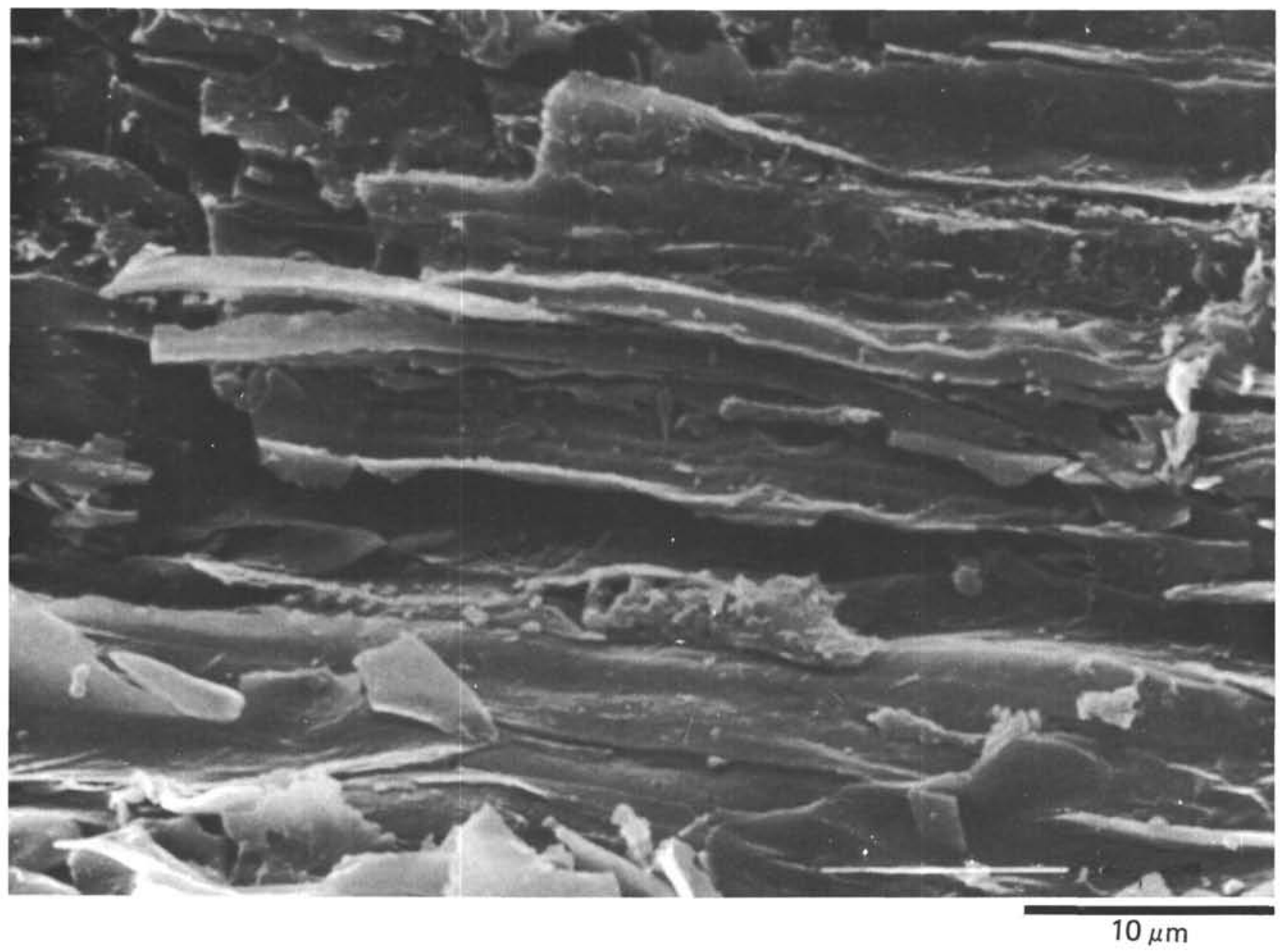

Figure 2. Scanning electron micrograph of single plant fragment showing fibrous structure.

of the major uplift shown on Figure 4. There are indices of resedimentation in this core which suggest that the plant material must have been deposited upslope before finding its final resting place. Indeed, since these fragments are land-derived, subaerial volcanic edifices presumably existed in the vicinity during the late Aptian-as they did in the mid-Pacific mountains-which could have provided the slopes necessary for redeposition. Consideration of these points indicates that the plant remains could initially have come to rest at depths somewhat less than $5 \mathrm{~km}$ before finding their final resting place as part of a slump-mass. Rapid redeposition may have aided the preservation of these carbonized fragments.

\section{DISCUSSION AND CONCLUSION}

A necessary concomitant of the oxygen-minimum model proposed to explain the presence of carbonaceous sediments on Pacific rises, as illustrated by Schlanger and Jenkyns (1976), was the condition that the deep bottom water in the basin was oxygenated. A matter for discussion, therefore, is whether the presence of the abundant plant remains in the deep-water sediments, described in the foregoing, contradicts the oxygen-minimum model. Given that plant remains are not an abundant constitutent of Recent abyssal sedi- ments, it follows that mid-Cretaceous bottom waters were probably less well ventilated than they are at present, a circumstance possibly explained by reduced bottom-water circulation during the Mesozoic. Assuming, however, that substantial amounts of organic matter have not been lost by thermal mobilization, we may turn for a more sophisticated examination of the significance of these fossil fragments to the review of organic Cretaceous matter from the North Atlantic by Tissot et al. (1979). According to these authors, three types of organic material are found in Cretaceous Atlantic sediments: "(A) organic matter of marine origin deposited in a reducing environment, (B) terrestrial organic matter transported and incorporated in the sediment with moderate degradation, and $(C)$ residual organic matter of terrestrial origin which has been highly degraded in sub-aerial soils prior to transportation"' (p. 362 of Tissot et al., 1979). In order for Type A material to be preserved in sediments, it must be exposed for a minimal time to oxygenated waters, or surface productivity must be very high, to enable even a small percentage of organic matter to reach the sediment/water interface and be preserved by burial. Type B material may be rapidly transported, deposited, and buried within sediments involved in slumping and turbidity current action. Furthermore, the already de- 


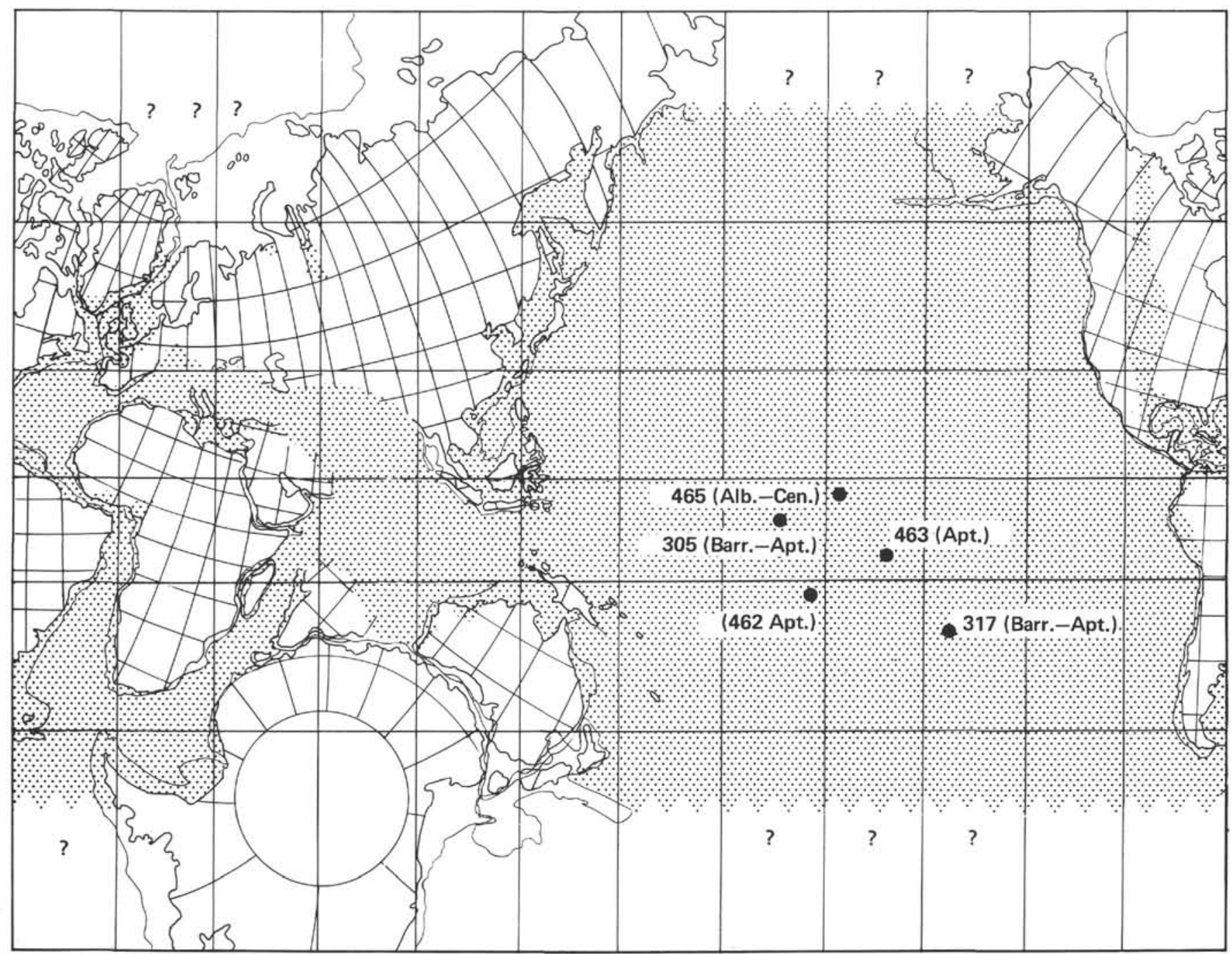

Figure 3. Putative expanded equatorial (or global?) distribution of deoxygenated intermediate water during the mid-Cretaceous (shown by dotted ornament). Within this zone, conditions were locally favorable for the accumulation and preservation of shales rich in organic matter. Pacific DSDP sites with Barremian, Aptian, and and Albian black carbonaceous sediments are shown in their mid-Cretaceous positions (after the method of Lancelot and Larson, 1975). 100-m.y.-old world map after Smith and Briden (1977). Data on distribution of deposits rich in organic material from Lancelot, Moberly, et al. (1975); Schlanger, Jackson, et al. (1979); Fischer and Arthur (1977); Arthur and Schlanger (1979); Vallier and Thiede et al. (1979); Jenkyns (1980).

graded nature of the carbonaceous material renders it less susceptible to oxidation. "Thus," say Tissot et al. (1979, p. 368), "preservation and accumulation of terrestrial organic matter is much less dependent on an oxygen depletion than accumulation of marine organic matter." The plant remains found in Core 40 from Hole $462 \mathrm{~A}$ are certainly of Type B and possibly Type C. Therefore, we believe that their presence does not require that there were anoxic conditions during Aptian time in the deep water of the Nauru Basin: the oxygenminimum model of Schlanger and Jenkyns (1976) for the Pacific remains unviolated. Tissot et al. (1979) consider that a 0.3 to $0.5 \%$ organic carbon content represents a "background" figure for Cretaceous Atlantic sediments.

Arthur and Natland (1979, p. 375) refer to the stratigraphic pattern of distribution of types of organic matter emerging from the DSDP work in the Atlantic:
"There is a high proportion of terrigenous organic matter in the carbonaceous sediment during Hauterivian through early Albian time, but marine organic matter was also preserved at times, especially after the middle Albian." The upper Aptian terrestrial organic matter preserved at Site 462 and upper Aptian terrestrial organic matter at Site 463 in the western mid-Pacific mountains contrast with the dominant marine organic matter in upper Albian to Cenomanian sediments drilled on the southern Hess Rise (Dean et al., 1979). It appears that the trend from a high terrestrial/low marine content ratio in Aptian to low terrestrial/high marine content ratio in Albian and younger sediments may also characterize parts of the Pacific Basin. However, proximity to vegetated islands must be another variable; this presumably explains the presence of terrestrial organic signatures in younger Cretaceous sediments (Cenomanian, Campanian, and Maestrichtian) of the Nauru 


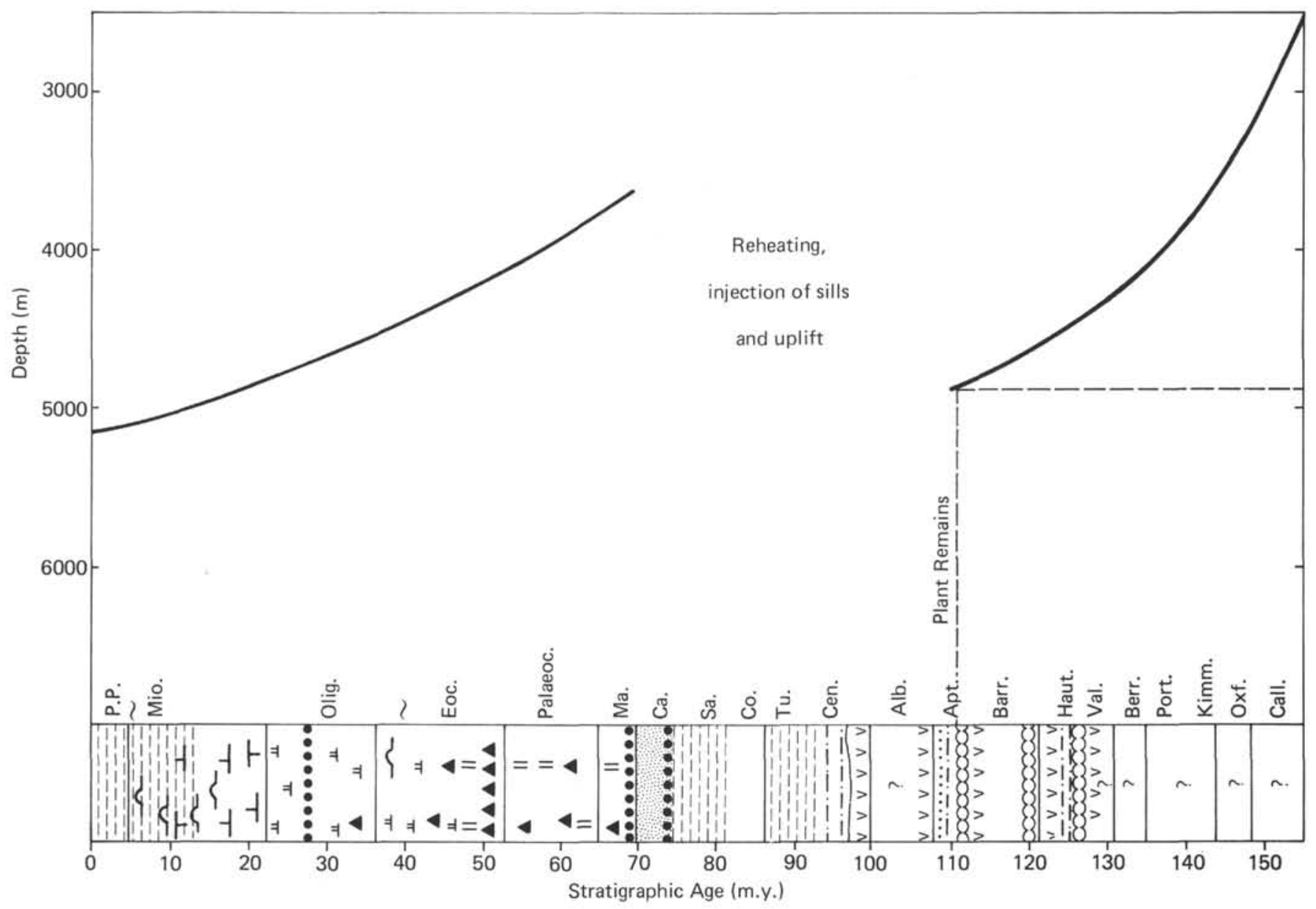

Figure 4. Postulated depositional depth of plan remains at $\sim 4800$ meters. Sea-floor-subsidence track after Schlanger and Premoli Silva (this volume).

Basin (Thomson et al., this volume). If this local effect is filtered out, there remains, however, some evidence that the change in the nature of entombed organic matter could be a global phenomenon, spotlighting, perhaps, an important difference in the nature of the Early and Late Cretaceous oceanic anoxic events.

\section{REFERENCES}

Arthur, M. A., and Natland, J. H., 1979. Carbonaceous sediments in the North and South Atlantic. The role of salinity in stable stratification of early Cretaceous basins. In Talwani, M., Hay, W., and Ryan, W. B. F. (Eds), Deep Drilling Results in the Atlantic Ocean: Continental Margins and Paleoenvironment. Maurice Ewing Series 3: Washington (Am. Geophys. Union), pp. 375-401.

Arthur, M. A., and Schlanger, S. O., 1979. Cretaceous "oceanic anoxic events" as causal factors in development of reef-reservoired giant oil-fields. Am. Assoc. Petrol. Geol. Bull., 63: 870-885.

Dean, W. E., Thiede, J., and Claypool, G. E., 1979. Origin of organicrich limestones of mid-Pacific Mountains and southern Hess Rise, central North Pacific Ocean. Geol. Soc. Am. Abstracts with Programs, 11 (no. 7):411. (Abstract)

Fischer, A. G., and Arthur, M. A., 1977. Secular variations in the pelagic realm. In Cook, H. E., and Enos, P. (Eds.), Deep-Water Carbonate Environments: Spec. Publ. Soc. Econ. Palaeont. Miner., 25:19-50.

Heath, G. R., Moore, T. C., Jr., and Dauphin, J. P., 1977. Organic carbon in deep-sea sediments. In Anderson, N. R., and Malahoff,
A. (Eds.), The Fate of Fossil Fuel $\mathrm{CO}_{2}$ in the Oceans: New York (Plenum Press), pp. 605-625.

Jenkyns, H. C., 1980. Cretaceous anoxic events: from continents to oceans. J. Geol. Soc. Lond., 137:171-188.

Lancelot, Y., and Larson, R. L., 1975. Sedimentary and tectonic evolution of the northwestern Pacific. In Larson, R. L., Moberly, R., et al., Init. Repts. DSDP, 32: Washington (U.S. Govt. Printing Office), 925-940.

Larson, R. L., Moberly, R., et al., 1975. Init. Repts. DSDP, 32: Washington (U.S. Govt. Printing Office).

Ryan, W. B. F., and Cita, M. B., 1977. Ignorance concerning episodes of oceanwide stagnation. Mar. Geol., 23:197-215.

Schlanger, S. O., Jackson, E. D., et al., 1976. Init. Repts. DSDP, 33: Washington (U.S. Govt. Printing Office).

Schlanger, S. O., and Jenkyns, H. C., 1976. Cretaceous oceanic anoxic events: causes and consequences. Geol. Mijnbouw., 55:179-184.

Smith, A. G., and Briden, J. C., 1977. Mesozoic and Cenozoic Paleocontinental Maps: Cambridge University Press.

Thiede, J., and van Andel, Tj. H., 1977. The paleoenvironment of anaerobic sediments in the Late Mesozoic South Atlantic Ocean. Earth Planet. Sci. Lett., 33:301-309.

Thierstein, H. R., 1979. Paleoceanographic implications of organic carbon and carbonate distribution in Mesozoic deep-sea sediments. In Talwani, M., Hay, W., and Ryan, W. B. F. (Eds.), Deep Drilling Results in the Atlantic Ocean: Continental Margins and Paleoenvironment. Maurice Ewing Series 3: Washington (Am. Geophys. Union), pp. 249-274.

Tissot, B., Deroo, G., and Herbin, J. P., 1979. Organic matter in Cretaceous sediments of the North Atlantic: contribution to sedimentology and paleogeography. In Talwani, M., Hay, W., 
and Ryan, W. B. F. (Eds.), Deep Drilling Results in the Atlantic Ocean: Continental Margins and Paleoenvironment. Maurice Ewing Series 3: Washington (Am. Geophys. Union), pp. 362-374.

Vallier, T., and Thiede, J., 1979. Leg 62 probes the paleoenvironments. Geotimes, 24 (no, 2): 24-26.
Voigt, E., 1962. Fr̈uhdiagenetische Deformation der turonen Plänerkalke bei Halle/Westf. als Folge einer Grossgleitung unter besonderer Berüchsichtigung des Phacoid-Problems. Mitt. Geol. Staat. Inst. Hamburg, 31:146-275. 